The Agriculturists 12(2): 103-115(2014) ISSN 2304-7321 (Online), ISSN 1729-5211 (Print)

\title{
An Ex-Post Analysis of Ginger (Zingiber officinalis) Research and Extension Investment in Bangladesh
}

\author{
Md. Kamrul Hasan ${ }^{1 *}$ and M. Serajul Islam² \\ ${ }^{1}$ Spices Research Centre, Bangladesh Agricultural Research Institute, Shibgonj, Bogra \\ Bangladesh; ${ }^{2}$ Dept. of Agricultural Economics, Bangladesh Agricultural University, Mymensingh \\ *Corresponding author and Email: kamrulspc@yahoo.com
}

Received: 20 February 2014

Accepted: 13 December 2014

\begin{abstract}
The study estimated the benefit and rate of returns to investment on ginger research and extension in Bangladesh. The Economic Surplus Model with ex-post analysis was used to determine the returns to investment and their distribution between production and consumption. Several discounting techniques were also used to assess the efficiency of ginger research. The adoption rate was found increasing over the period. The yield of modern varieties of ginger developed by Bangladesh Agricultural Research Institute (BARI) was 78 per cent higher than that of the local varieties. Society got net benefit of Tk. 432.31 million by investing in ginger research and extension. The net present value (NPV) and present value of research cost (PVRC) were estimated to beTk. 135.01 and 81.15 million, respectively. The internal rate of return (IRR) and benefit cost ratio (BCR) were estimated to be 32 per cent and 3.75 , respectively indicating that investment on ginger research and development was profitable. Ginger seed production programme should be taken largely to increase production by increasing improved variety adoption area.
\end{abstract}

Keywords: Ginger, investment, returns, adoption, yield advantage, benefit and rate of return

\section{Introduction}

Ginger (Zingiber officinalis) is one of the most common and popular spices which is widely used in manufacturing a number of food products like; ginger bread, confectionary, ginger ale, curry powder, certain curried meats, table sauces, in pickling and in the manufacture of certain soft drinks like; cordials, ginger cocktail, carbonated drinks etc. It has medicinal values as well. Ginger is also used for the preparation of ginger oil, oleoresin, essences and tinctures. A number of alcoholic beverages are prepared from ginger in different countries of the world, such as; ginger brandy, ginger wine, ginger beer etc. (Bose, et al., 1999). It is a principal ingredient of curry paste in the Bangladeshi kitchen.

In 2001/02, just before development and introduction of improved varieties of ginger in Bangladesh, national yield per hectare was only 5.69 tonnes per hectare which was much lower than the production at research station. It was because of lack of sufficient improved varieties and practice of traditional cultural method followed by the farmers. The productivity trend has been increasing since 2003-04 (Figure 1) and in $2007 / 08$, productivity reached to 7.65 tonnes per hectare, due to develop and dissemination of improved varieties of ginger (BBS, 2012). 


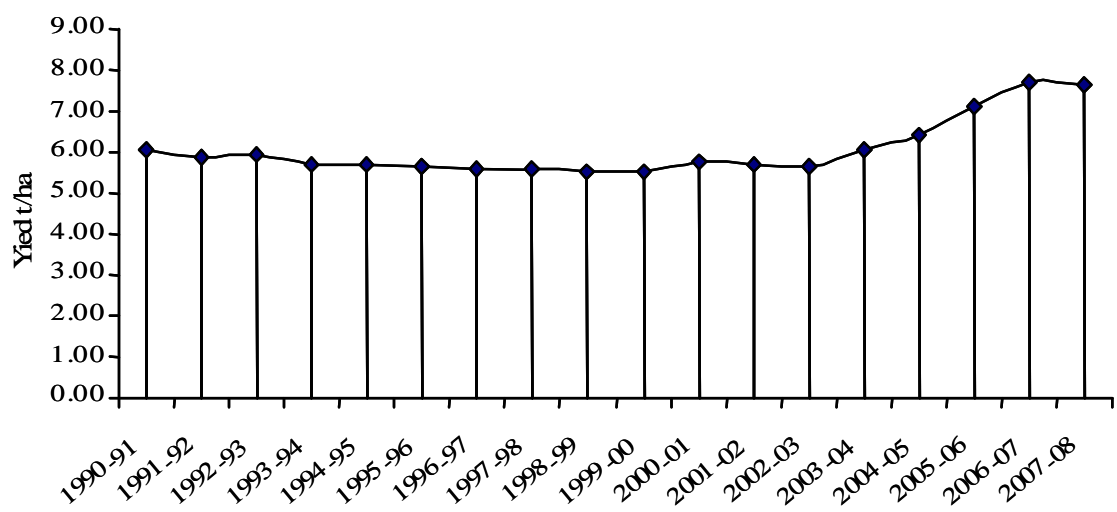

Figure 1. Yield trend of ginger

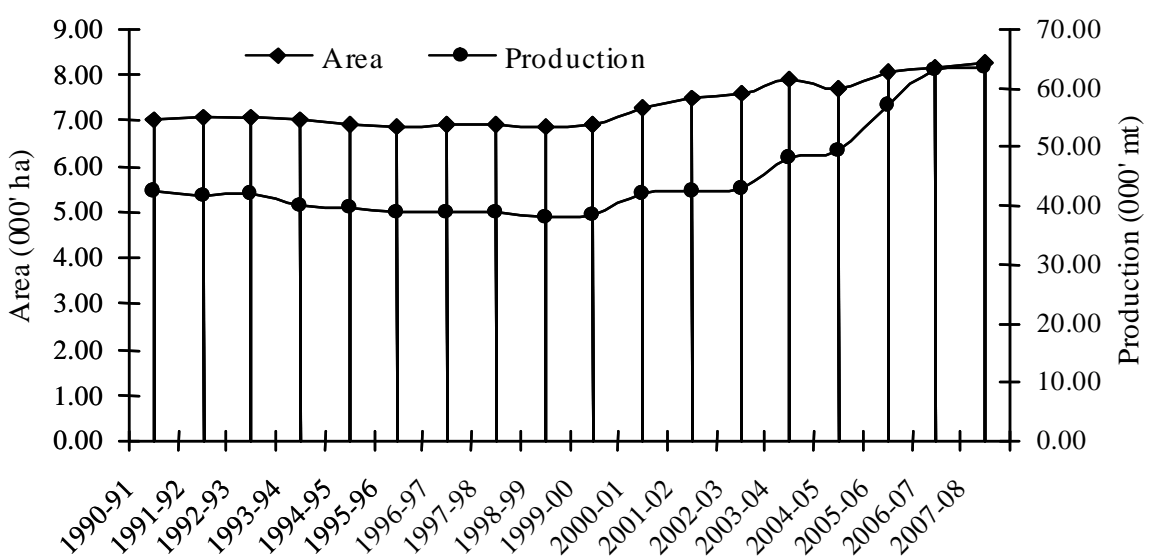

Figure 2. Area and production trend of ginger

National productivity will be further increased with the increased adoption of improved variety of ginger in farmers' field and more area coverage which will results getting higher income of the farmer (Figure 2). Growing area of ginger increased from 7500 hectares of land in 2001-02 to 8280 hectares in 2007-08. On the other hand, production increased from 4266 metric tonnes in 2001-02 to 6339 metric tonnes in 2007-08 (BBS, 2003, 2009).

Due to increasing population, demand for cereal crops increased significantly. To meet up this demand, ginger crops land is being diverted to cereal food crop cultivation, which results in a big gap between production and demand. To meet up this extra demand, the country has to spend a huge amount of foreign currency for importing ginger every year.

Realizing the importance of ginger, ginger research has been strengthened through the Spices Research Centre of BARI since 1996-97. BARI has already released one improved ginger variety named BARI Ginger- 1.

The variety is cultivated in the farmers' fields since it was released. BARI in association with 
BARC (Bangladesh Agricultural Research Council) and DAE (Department of Agricultural Extension), has strengthened the research and extension works to improve ginger production.

The study was taken to examine the adoption of improved variety of ginger and its yield advantages over local varieties; to measures the social benefits derived from ginger research and extension activities and finally to estimate the rate of return of ginger research and extension in Bangladesh. However, this study provided information for the policy makers, donors, researchers, extension people and the public on the contribution and the rate of return to investment in ginger research in Bangladesh.

\section{Methodology}

\subsection{Sources of data}

For the present study, the data were collected from different published and unpublished reports, and informal scientists' interview. The area, production and yield of BARI Developed Modern Variety (BDMV) of ginger were collected from Spices Research Centre; adoption rates were collected through informal scientists' interview; and harvest price and consumer price index (CPI) were collected from various issues of Statistical Yearbooks (1996-2008) published by the Bangladesh Bureau of Statistics. The supply elasticity was taken from the study conducted by Day and Norton (1993). Since Spices Research Centre (SRC) of BARI is the main organization for ginger research, the data on research cost included mainly from SRC of BARI. The extension and promotion activities were done by DAE and the data on related costs were collected from this organization. BARC mainly provided the data on administrative costs. The on-farm yield data of BDMV ginger variety were collected from the SRC, Bogra. Data on the input cost change was calculated by the researcher through analyzing increased production, higher labour costs for harvesting and transporting, higher cost of modern seeds, and slightly more fertilizers application for improved variety than for traditional varieties.

\subsection{Analytical procedure}

The collected data were analyzed using graphical, tabular and statistical methods.

\subsubsection{Estimation of returns to investment}

The Economic Surplus Model (ESM) with ExPost analysis was used to estimate the rate of returns to investment in ginger research and extension. The analysis was done under small open-economy market situation. The theoretical concept of ESM has been illustrated below.

Theoretical concept of economic surplus model (ESM): The concept of economic surplus was used to measure economic welfare and the changes in economic welfare from policy and other interventions (Alston et al., 1995; Currie et al., 1971). Usually, the economic surplus concept is adopted to estimate the benefits from the adoption of improved varieties. The components of economic surplus are consumer surplus and producer surplus. Given the initial condition (i.e., pre-research supply curve $S_{1}$ and demand curve $\mathrm{D}_{1}$ ), consumer surplus is depicted as Area $P_{0} P_{n} b$ in Figure 3. This is the surplus or benefit to consumers because of a functioning market. Consumer surplus is that area beneath the demand curve less the cost of consumption. The cost of consumption is the area below the price line $P_{n}$.

Producer surplus is defined by the area $\mathrm{P}_{\mathrm{n}} \mathrm{bO}$ in Figure 3. Area $\mathrm{P}_{\mathrm{n}} \mathrm{bO}$ in the surplus left to the farmers after they have paid for the total costs of production, area $\mathrm{ObQ}_{\mathrm{n}}$ (Alston et al., 1995). The adoption of an intervention by farmers, such as an improved variety usually means one of two things: (i) a farmer can supply more of the commodity using the same level of resources (i.e. same land area and other inputs), or (ii) a farmer can supply the same level of commodity output but does it with fewer resources. In either case, this is depicted by a shift to the right of the supply curve as shown in Figure 3 (the shift is from $S_{1}$ to $S_{2}$ ). The shift is the supply curve from the adoption of an intervention changes the initial equilibrium price and quantity of the commodity. This new price quantity equilibrium 
increases economic surplus. The change in economic surplus (economic benefits) is measured by comparing the difference in economic surplus between the pre-adoption period and the post-adoption period.

Given a shift in the supply curve $S_{1}$ to $S_{2}$, the change in consumer surplus is depicted in Figure 3 as Area $a b c+$ Area $P_{n} b_{a P}$. The shift in the supply curve (due to the adoption of an intervention) has decreased the price consumers now have to pay for the commodity.

Given a shift in the supply curve $S_{1}$ to $S_{2}$, the change in producer surplus is depicted in Figure 3 as Area Oac-Area $\mathrm{P}_{\mathrm{n}} \mathrm{baP}_{0}$. Area Oac represents the decrease in the cost of production the same unit of the commodity that farmers now enjoy because they are using the intervention. This represents the benefits to the farmers from adopting the intervention and can be measured and quantified in monetary terms. The adoption of the intervention, however, has increased the quantity produced thereby decreasing the price of the commodity ( $\mathrm{P}_{\mathrm{n}}$ to $\mathrm{P}_{0}$ in Figure 3 ) and is a loss to farmers income. Farmers can recover some of this loss since they can sell more quantity $\left(\mathrm{Q}_{\mathrm{n}}\right.$ to $\mathrm{Q}_{0}$ in Figure 3) of the commodity.

The total social benefits to society from the adoption of an intervention is the summation of the change in consumer surplus plus the change in producer surplus (Area abc + Area Oac) minus the input cost change from adopting the new interventions.

For a closed economy model, the estimated price elasticity of demand is used in the above formulas. For small open-economy model where the elasticity of demand is perfectly elastic, use a sufficiently large number of $\eta$ (Nagy et al., 2000). A small open economy market is one where the amount of exports or imports is small relative to total world trade in the commodity. Thus, there is little or no effect on the world price of the commodity (the small country assumption). In this case, the price of commodity does not change with the shift in the supply curve. For this study, the Bangladesh ginger market is modelled as a small open economy market.

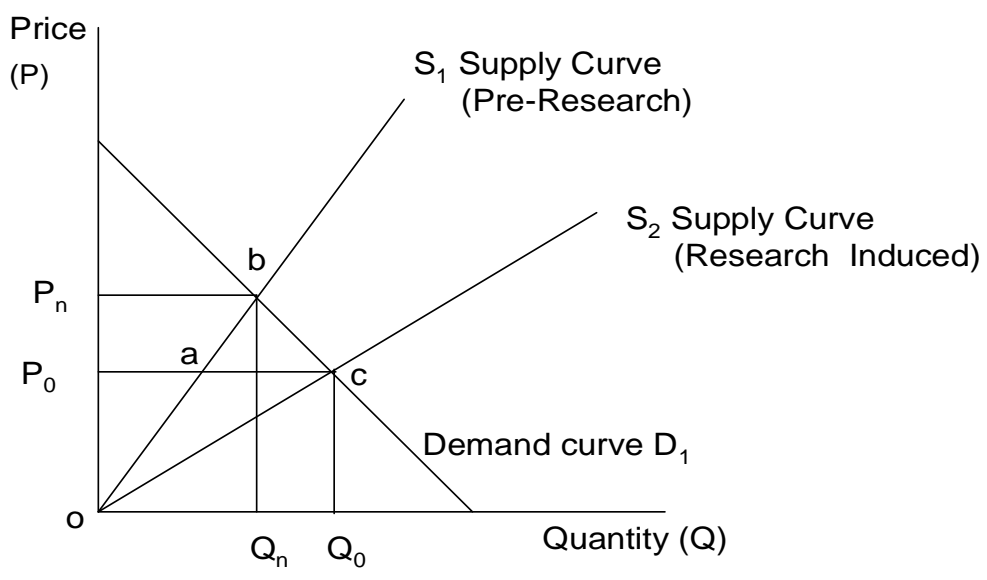

Figure 3. Economic surplus model (closed economy)

Change in Consumer Surplus Change in Producer Surplus
$=$ Area $a b c+$ Area $P_{n} b a P_{o}$

$=$ Area Oac-Area $\mathrm{P}_{\mathrm{n}} \mathrm{baP}_{\mathrm{o}}$ 


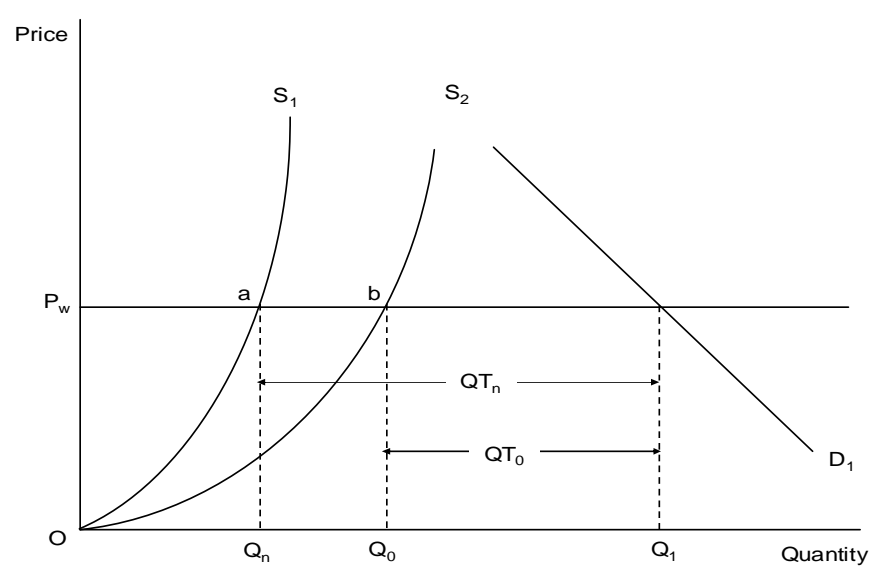

Figure 4. Small open-economy importer economic surplus model

The change in economic surplus for a small open-economy that is domestically produced but allows imports to cover shortfall (i.e., the Bangladesh ginger market) is depicted Figure 4. The world price $\mathrm{P}_{\mathrm{w}}$ and quantity demanded by Bangladeshi consumers $Q_{1}$ defines the initial equilibrium. At price $\mathrm{P}_{\mathrm{w}}$, producers supply $\mathrm{Q}_{\mathrm{n}}$ amount of ginger when faced by the pre-research supply curve $S_{1}$. Ginger imports are equal to $\mathrm{QT}_{\mathrm{n}}$. When faced by the research induced supply curve $S_{2}$ (the supply curve that exist because farmers have adopted new high yielding varieties). Ginger producers increased production to quantity $\mathrm{Q}_{\mathrm{n}}$ and increase $\mathrm{Q}_{\mathrm{n}} \mathrm{Q}_{0}$. Ginger imports are decreased by the same amount as the increase in production $\mathrm{Q}_{\mathrm{n}} \mathrm{Q}_{0}$ and are now at $\mathrm{QT}_{0}$. Since $\mathrm{P}_{\mathrm{w}}$ does not change (small economy assumption), there is no change in consumer surplus- consumers are neither better off nor worse off. The enter change in economic surplus from the adoption of new ginger varieties is thus a change in producer surplus only and is identified by area oab in Figure 4 (corresponds to area oac in Figure 3). The amount of foreign exchange saved by the adoption of improved varieties is equal to $P_{w} \times\left(Q_{n} Q_{0}\right)$.

Empirical approach: The Akino and Hayami (1975) approximation formulas for calculating changes to producer and consumer economic surplus are described below and these are used in this study. The Akino and Hayami (1975) approximation formulas for calculating the change in economic surplus for a closed economy analysis (Figure 3) is as follows:
Area A (abc)

Area B (Oac)

Area $\mathrm{C}\left(\mathrm{P}_{\mathrm{n}} \mathrm{baP}_{\mathrm{o}}\right)$

Where,

$$
\begin{array}{ll}
= & 0.5 \mathrm{P}_{\mathrm{o}} \mathrm{Q}_{\mathrm{o}}\left((\mathrm{k}(1+\gamma))^{2} /(\gamma+\eta)\right) \\
= & \mathrm{kP}_{\mathrm{o}} \mathrm{Q}_{\mathrm{o}} \\
= & \left(\left(\mathrm{P}_{\mathrm{o}} \mathrm{Q}_{\mathrm{o}} \mathrm{k}(1+\gamma)\right) /(\gamma+\eta)\right) \times(1-((0.5 \mathrm{k}(1+\gamma) \eta) /(\gamma+\eta))-0.5 \mathrm{k}(1+\gamma))
\end{array}
$$

$\mathrm{P}_{\mathrm{o}} \quad=$ Price of ginger $(\mathrm{Tk} / \mathrm{ton})$ (Existing market price)

$\mathrm{Q}_{\mathrm{o}} \quad=$ Production of BDMV ginger (ton) (Existing production)

$\mathrm{P}_{\mathrm{n}}=$ Quantity price that would exist in absence of research

$\mathrm{Q}_{\mathrm{n}}=$ Quantity of the ginger produced that would exist in absence of research

$\mathrm{k} \quad=$ Horizontal supply shifter

$\gamma=$ Price elasticity of ginger supply

$\eta=$ Absolute price elasticity of the demand for the commodity. 
The supply shifter (k): The supply shifter ' $\mathrm{k}$ ' is the overall yield advantage of improved varieties of ginger over the local variety weighed by the area sown to the improved variety of ginger. In the case of the Akino and Hayami (1975) approximation formulas, $\mathrm{k}$ is the horizontal shift from the equilibrium price $P_{n}$ given $S_{1}$ to the equilibrium price $P_{0}$ given $S_{2}$ which corresponds to a distance equal to $\mathrm{Q}_{\mathrm{n}} \mathrm{Q}_{\mathrm{o}}$ in Figure 3 (Gardener et al., 1986; Nagy and Furtan, 1978). The supply shifter $\mathrm{k}$ is calculated as follows:

$$
\left.k_{t}=\sum_{i=1}^{n}\left[1-\frac{Y_{t}}{Y_{i t}}\right)\right] \times A_{i t}
$$

Where,

Yit $=$ Yield of the improve varieties of ginger in year $\mathrm{t}$

$\mathrm{Yt}=$ The yield of a base (or average yield of local variety ginger) that has been gown in the past and that would still be grown if no new varieties had been developed

Ait=The proportion of the total area sown to improved variety of ginger in year $t$

$\mathrm{N}=$ The number of improved ginger variety

Estimation of net present value (NPV)

The amount of total funds returned from the investment in research is called NPV. The NPV of the benefits was calculated by using the following formula:

$$
N P V=\left[\sum_{i=1}^{n}\left(T S B_{t}-C_{t}\right)(1+r)^{-t}\right]
$$

Where,

$\mathrm{C}_{\mathrm{t}}=$ The cost of research and extension investment in year $\mathrm{t}$

$\mathrm{r}=$ The discount rate

$\mathrm{n}=$ The time horizon over which the benefits of the research investments are realized

\section{Internal rate of return (IRR):}

The IRR was calculated relating to the total social benefit (TSB) minus an input cost change, if any, in each year to the research expenditure (C) in each year and is the discount rate that results in a zero net present value of the benefits. The IRR is calculated as:
$O=\left[\sum_{t=1}^{n}\left(T S B_{t}-C_{t}\right)(1+I R R)^{-t}\right]$

The IRR can be defined as the rate of interest that makes the accumulated present value of the flow of costs equal to the discounted present value of the flow of returns, at a given point in time (Peterson, 1971).

\section{Results and Discussion}

\subsection{Adoption status and yield advantages of} $B A R I$ developed modern ginger variety

Foster and Rosenzweig (2010) pointed out that "adoption and input use are the outcomes of optimizing by heterogeneous agents". The adoption of improved variety is very important factor by which the volume of change in economic surplus is determined. The more the adoption of improved variety over traditional one, the higher is the changes in surplus. Apart from this, it gives us feedback as to why and how well a technology is being accepted by the farmers. So far, there is no ginger varietal adoption survey report in Bangladesh. The existing variety survey information along with the considerable field experience of the ginger scientists is used to sketch out the percentage area sown by variety grouping which are presented in Table 1. Rusike et al. (2010) used PSM (propensity score matching) alongside DD (double difference) in investigating adoption rates of new varieties.

Modern ginger variety named BARI Ginger-1 was released in 2009. Before releasing this variety, the Accession No. of this variety was G001. To increase the production of ginger, Bangladesh Government had taken programme named Action Plan from 2002-03 through the Ministry of Agriculture. Dissemination of the variety was started at that time through DAE. Spices Research Centre of BARI supplied the seed (rhizome) to DAE named G-001. The area covered by of BARI Ginger-1 was 1 per cent in 2002-03, which has gradually increased to 15 per cent in 2007-08 (Table 1). The annual rate of adoption of BARI Ginger-1 was 2.50 per cent (Table 2). 


\section{Supply shifter k}

The supply shifter $\mathrm{k}$ identifies the amount of production that can be attributed to the varietals improvement research in each year (i.e., the shift in the supply curve). The more the value of supply shifter the more is the shift in the supply curve, resulting higher benefit to the society. The supply shifter is the outcome of the simultaneous force of adoption percentage and yield advantage. It was calculated using the formula discussed in methodology. Table 3 shows each year adoption percentage and supply shifter of ginger. It was observed that the rate of shift has gradually increased. The shifter accounted for the yield advantage of BARI developed ginger variety over the traditional variety. The supply shifter of ginger was found to be 0.117 for the year 2007/08; meaning that $12 \%$ more ginger production was made available during 2007/08 because of farmers' adoption of BARI developed ginger variety.

\section{Yield advantages}

This is very important factor to determine the economic surplus. The higher yield advantage always ensures higher level of economic surplus. Two types of data exist in most of the less developed countries for good estimation of yield advantage (YA) as well as the aggregate production function shifter. They are on-station yield trial data and on-farm yield data. The onstation yield data is readily available and most often the only reliable source. One of the arguments against using on-station yield trial data is that superior management practices and techniques are used and therefore, the results may not reflect on the on-farm situation. Another argument placed by different author (Hertford et al., 1971 \& 1977; Ayer et al., 1972; Akino et al. 1975; Scobie et al., 1977 and Nagy et al., 1978) and showed that the yield advantage estimation from the on-station yield trial data would be biased upward because the estimation might also include the contribution made by inputs such as fertilizer and water. To account for this problem, the estimated yield advantage of new varieties by estimating production functions of yield as a function of new varieties and other inputs. This process requires a substantial data which is not readily available in Bangladesh.

Table 1. Area of traditional variety replaced by BDMVs of ginger

\begin{tabular}{lllllll}
\hline Year & \multicolumn{2}{l}{ Total ginger } & area & \multicolumn{2}{l}{ Area of LVs of ginger } & \multicolumn{2}{l}{$\begin{array}{l}\text { Area covered by BARI } \\
\text { Ginger-1(G-001) }\end{array}$} \\
\cline { 2 - 7 } & Hectare & $\%$ & Hectare & $\%$ & Hectare & $\%$ \\
\hline $1996-97$ & 6899 & 100 & 6899 & 100.00 & 0 & 0.00 \\
$1997-98$ & 6913 & 100 & 6913 & 100.00 & 0 & 0.00 \\
$1998-99$ & 6877 & 100 & 6877 & 100.00 & 0 & 0.00 \\
$1999-00$ & 6909 & 100 & 6909 & 100.00 & 0 & 0.00 \\
$2000-01$ & 7296 & 100 & 7296 & 100.00 & 0 & 0.00 \\
$2001-02$ & 7498 & 100 & 7498 & 100.00 & 0 & 0.00 \\
$2002-03$ & 7573 & 100 & 7497 & 99.00 & 75.73 & 1.00 \\
$2003-04$ & 7917 & 100 & 7759 & 98.00 & 158.34 & 2.00 \\
$2004-05$ & 7715 & 100 & 7406 & 96.00 & 308.58 & 4.00 \\
$2005-06$ & 8045 & 100 & 7482 & 93.00 & 563.12 & 7.00 \\
$2006-07$ & 8148 & 100 & 7252 & 89.00 & 896.26 & 11.00 \\
$2007-08$ & 8283 & 100 & 7041 & 85.00 & 1242.45 & 15.00 \\
\hline
\end{tabular}

Note: BDMV- BARI Developed Modern Variety, LVs- Local Varieties and shaded area indicates no improved varieties were released. 
Table 2. Adoption rate of BARI Developed Modern Varieties of Ginger

\begin{tabular}{lcc}
\hline \multicolumn{1}{c}{ Name of crop } & Varietals Name & Adoption rate (\%) \\
\hline Ginger & BARI Ginger-1 (G-001) (2000-01 to 2007-08) & 2.50 \\
\hline
\end{tabular}

Table 3. Calculation of the supply shifter $(\mathrm{K})$ of BARI Ginger over traditional variety

\begin{tabular}{ccc}
\hline Year & \% Area of BARI Ginger-1 replacing LVs & Supply Shifter K \\
\hline $1996-97$ & 0 & 0.0000 \\
$1997-98$ & 0 & 0.0000 \\
$1998-99$ & 0 & 0.0000 \\
$1999-00$ & 0 & 0.0000 \\
$2000-01$ & 0 & 0.0000 \\
$2001-02$ & 0 & 0.0000 \\
$2002-03$ & 1 & 0.0078 \\
$2003-04$ & 2 & 0.0157 \\
$2004-05$ & 4 & 0.0313 \\
$2005-06$ & 7 & 0.0548 \\
$2006-07$ & 11 & 0.0861 \\
$2007-08$ & 15 & 0.1174 \\
\hline
\end{tabular}

Table 4. Yield advantages of improved varieties of ginger over traditional varieties

\begin{tabular}{lcccc}
\hline $\begin{array}{l}\text { Name of ginger } \\
\text { crop }\end{array}$ & $\begin{array}{l}\text { Average (weighted) } \\
\text { yield of Improved } \\
\text { variety (t/ha) }\end{array}$ & $\begin{array}{l}\text { Average yield of } \\
\text { traditional variety } \\
(\mathrm{t} / \mathrm{ha})\end{array}$ & $\begin{array}{l}\text { Yield } \\
\text { difference } \\
(\mathrm{t} / \mathrm{ha})\end{array}$ & $\begin{array}{l}\text { Yield } \\
\text { advantage }\end{array}$ \\
\hline BARI Ginger-1 & 28.380 & 6.16 & 22.22 & 0.783 \\
\hline
\end{tabular}

For the present study, on-farm yield trial data were considered as a more reliable source for the calculation of yield advantage rather than the onstation yield data in Bangladesh. The yield advantages for this study have been calculated following Gardiner et al. (1986), Nagy et al. (1978) and Nagy (1991).

Spices Research Centre (SRC) of BARI developed variety: BARI Ginger-1 that has replaced the traditional varieties since 2002-03.

The weighted yields were calculated by taking the average of the irrigated optimum, late irrigated and non irrigated yield multiplied by the mean of irrigated, late irrigated and non irrigated area of ginger. Per hectare average yield of improved variety of ginger i.e. BARI Ginger1 was found to be 28.38 tonnes. In case of traditional variety it was only 6.16 tonnes. Therefore, the yield advantage of BARI Ginger1 over traditional variety was found to be $78 \%$ (Table 4).

\subsection{Estimating benefits from ginger research and extension}

This section deals with the estimation of returns to investment in ginger research and extension using the economic surplus approach. This approach estimates the benefits to agricultural research by measuring the change in consumers' surplus (CS) and producers' surplus (PS) from a rightward shift in the supply curve that is brought about through technological change. It should be mentioned here that aggregate consumers' surplus, producers' surplus and total surplus were calculated by summing up corresponding surpluses of all ginger rather 
than summing up from the areas of the model. In order to calculate the net benefits (NB), research and extension expenditures are subtracted from total surplus. All these estimates of benefits are expressed in real term by using 2007-08 constant prices. The rate of returns and NB are then discounted using $10 \%$ interest rate for obtaining the efficiency of investment. First, the yearly total social benefits are estimated using the small-open economy model (Figure 4).

This is done by assigning a very high number to the demand elasticity parameter ( $\mathrm{y}$ ) since in a small open-economy model, $y$ is perfectly elastic. The analysis is undertaken for each year $1996 / 97$ to $2007 / 08$ for ginger.

Ginger research and extension in Bangladesh seemed to be continued by three different organizations. The Organizations are Bangladesh Agricultural Research Institute (BARI), Bangladesh Agricultural Research Council (BARC) and Department of Agricultural
Extension (DAE). The ginger research and extension expenditure comprised the expenditure of three organizations are furnished in the following sequence.

The year wise expenditures behind variety development and dissemination for the new varieties of ginger to the farmers are shown in Table 5. The expenditures of BARI/SRC and BARC were estimated from 1996/97 to 2007/08. The accumulated expenditures over the years of BARI/SRC and BARC were estimated at Tk. 85.39 and 7.70 million, respectively. Extension expenditures and input cost change were estimated after development of improved variety, which has started since 2002/03. The cumulative expenditures of varietal dissemination by extension department and input cost changes were amounted at Tk. 12.47 and 20.20 million, respectively. Over the years, expenditures accruing for BARI/SRC, BARC, DAE and input cost change were Tk. 125.76 million.

Table 5. Ginger research and extension expenditure by sources 1996/97-2007/08

\begin{tabular}{|c|c|c|c|c|c|c|}
\hline Year & $\begin{array}{l}\text { Total } \\
\text { SRC/BARI } \\
\text { Research } \\
\text { Expenditures } \\
\text { (current Taka) }\end{array}$ & $\begin{array}{l}\text { BARC } \\
\text { Administrative } \\
\text { Expenditures } \\
\text { (current Taka) }\end{array}$ & $\begin{array}{l}\text { Total } \\
\text { Extension } \\
\text { Expenditures } \\
\text { (current Taka) }\end{array}$ & $\begin{array}{l}\text { Input } \\
\text { cost } \\
\text { change } \\
\text { (current } \\
\text { Taka) } \\
\end{array}$ & $\begin{array}{l}\text { Total } \\
\text { Expenditures } \\
\text { (current Taka) }\end{array}$ & $\begin{array}{l}\text { Total } \\
\text { Expenditures } \\
\text { (2007-08 Tk.) }\end{array}$ \\
\hline $1996 / 97$ & 7788000 & 261250 & 0 & 0 & 8049250 & 14723300 \\
\hline $1997 / 98$ & 8699064 & 675850 & 0 & 0 & 9374914 & 16415928 \\
\hline $1998 / 99$ & 2882220 & 1181750 & 0 & 0 & 4063970 & 6777341 \\
\hline 1999/00 & 1728804 & 1221000 & 0 & 0 & 2949804 & 4685034 \\
\hline 2000/01 & 2132064 & 1114500 & 0 & 0 & 3246564 & 4880802 \\
\hline 2001/02 & 1985280 & 645000 & 0 & 0 & 2630280 & 3730468 \\
\hline $2002 / 03$ & 3334320 & 173500 & 1396915 & 377259 & 5281994 & 7067297 \\
\hline 2003/04 & 3859020 & 271300 & 1639660 & 836119 & 6606099 & 8338630 \\
\hline $2004 / 05$ & 14129808 & 301300 & 1887802 & 1727345 & 18046255 & 21489724 \\
\hline 2005/06 & 13091496 & 442200 & 2113068 & 3341282 & 18988046 & 21331341 \\
\hline 2006/07 & 11586960 & 724950 & 2686865 & 5636878 & 20635652 & 21870073 \\
\hline $2007 / 08$ & 14171520 & 690350 & 2745121 & 8282848 & 25889839 & 25889839 \\
\hline Total & 85388556 & 7702950 & 12469431 & 20201731 & 125762667 & 157199777 \\
\hline
\end{tabular}

Note : $\$ 1.00=$ Tk. 80.00

For the analysis, the current total expenditures were converted to 2007/08 constant prices using the Bangladesh Middle Income Group CPI Index and it was Tk 157.20. 
Table 6. Estimation of surplus from ginger research and extension investments

\begin{tabular}{llllll}
\hline Year & $\begin{array}{l}\text { Change in } \\
\text { consumer } \\
\text { surplus (Tk.) }\end{array}$ & $\begin{array}{l}\text { Change in } \\
\text { producer surplus } \\
(\text { Tk.) }\end{array}$ & $\begin{array}{l}\text { Change in } \\
\text { total surplus } \\
(\text { Tk. })\end{array}$ & $\begin{array}{l}\text { Total expenditure } \\
\text { (Based on 2007- } \\
\text { 08 Tk.) }\end{array}$ & $\begin{array}{l}\text { Net Benefit } \\
\text { (Tk) }\end{array}$ \\
\hline A & B & C & D=B+C & E & F=D-E \\
\hline $1996 / 97$ & 0 & 0 & 0 & 14723300 & -14723300 \\
$1997 / 98$ & 0 & 0 & 0 & 16415928 & -16415928 \\
$1998 / 99$ & 0 & 0 & 0 & 6777341 & -6777341 \\
$1999 / 00$ & 0 & 0 & 0 & 4685034 & -4685034 \\
$2000 / 01$ & 0 & 0 & 0 & 4880802 & -4880802 \\
$2001 / 02$ & 0 & 0 & 0 & 3730468 & -3730468 \\
$2002 / 03$ & 0.130 & 11897564 & 11897564 & 7067297 & 4830267 \\
$2003 / 04$ & 0.285 & 26124558 & 26124558 & 8338630 & 17785928 \\
$2004 / 05$ & 0.889 & 82248975 & 82248976 & 21489724 & 60759252 \\
$2005 / 06$ & 1.517 & 142159803 & 142159805 & 21331341 & 120828464 \\
$2006 / 07$ & 1.302 & 124208315 & 124208316 & 21870073 & 102338244 \\
$2007 / 08$ & 2.087 & 202872826 & 202872828 & 25889839 & 176982989 \\
\hline Total & 6.21 & 589512041 & 589512047 & 157199777 & 432312271 \\
\hline
\end{tabular}

Note : $\$ 1.00=$ Tk. 80.00

The total changes over years in consumers' and producer' surplus were estimated Tk. 6.21 and Tk. 589.51 million, respectively from ginger research and extension. Consumers' surplus was very much lower compared to producers' surplus due to perfect elasticity of demand for ginger in the small-open economy market. The estimated total surplus/total benefits ranged from Tk. 11.90 million in $2002 / 03$ to 202.87 million in $2007 / 08$ and the total surplus accrued as Tk. 589.51 million from the ginger research and extension in Bangladesh. Besides, the total net benefits obtained from ginger research and extension was Tk. 432.31 million for the year 1996/97 to 2007/08 (Table 6).

\subsection{Rate of return to ginger research and extension}

The rates of returns are the indicators of the investment efficiency of the research programme. There are many types of measure that can be used to estimate the rates of return. Among them, Net Present Value (NPV) of benefit, External Rate of Return (ERR) and Internal Rate of Return (IRR) were considered as the rates of return to ginger research and extension investments in Bangladesh. For comparing the net benefits with the total research costs, Present Value of Research Costs (PVRC) was also calculated. All the estimates were calculated at constant $(2007 / 08)$ prices with $10 \%$ discount rate. Table 7 was used to calculate the NPV, PVRC, ERR, IRR and BCR under smallopen economy condition. Under open economy, the producers' benefits were found much higher compared to consumers' benefits since the elasticity of demand for ginger were very high.

Table 7 revealed that society was benefited substantially from the investment in ginger research and extension in Bangladesh. The NPV of benefit indicates the total social benefit for a country and it was found negative up to 2001/02 and then it was positive. It means that the country did not receive any benefit from ginger research up to 2001/02 (Table 6). After 2001/02, the country as a whole was benefited with a big amount and found increasing trend up to 2007/08. The NPV was found to be Tk 135.01 million while PVRC over the period was Tk 81.15 million for ginger research and extension investment. The ERR was found to be $312.50 \%$. This means that the average taka spent on research and extension in ginger earn return $10 \%$ 
annually from the start of the initial investment $(1996 / 97)$ and is now paying off at the rate of $312.50 \%$ annually into perpetuity. In the benefit/cost mode, using $10 \%$ external interest rate, a one taka investment returned 31.25 taka over the period. The IRR of $32 \%$ means that on the average, each taka invested in ginger research and extension returned $32 \%$ annually from the date of the initial investment. It implies that the expenditure on ginger research and extension (Tk 81.15 million) could have been borrowed at $32 \%$ real rate of interest without incurring loss (Table 7). The benefit cost ratio was found to be 3.75 for ginger. The IRR and BCR will be increased by increasing the adoption of improved variety of ginger. The value of the parameter indicated that the investment in research and extension of ginger in Bangladesh is a good and profitable investment.

\subsection{Foreign exchange savings}

The yearly increase in production due to research save the country's foreign exchange to a remarkable extends. First, the research induced productions for ginger for the past years was calculated by multiplying the country's total ginger production by their respective production function shifter $\mathrm{k}$. Multiplying the results by world ginger price, foreign exchange savings was obtained. Considerable amounts of ginger are imported in Bangladesh every year to meet the internal demand for increasing population. The imported value of ginger was Tk. 570.53 million (BBS 2009). In reality, the amount imported is higher due to the illegal boarder trade of ginger from neighbouring countries. Thus, the increased production attributed to ginger improvement saved foreign exchange amounting to $\mathrm{Tk}$. 762.84 million from ginger research and extension (Table 8).

Table 7. Estimated rates of returns to ginger research and extension

\begin{tabular}{|c|c|c|c|c|c|}
\hline \multirow[t]{2}{*}{$\begin{array}{l}\text { Name of } \\
\text { crop }\end{array}$} & $\begin{array}{l}\text { Net present } \\
\text { value (NPV) }\end{array}$ & $\begin{array}{l}\text { Present value of } \\
\text { research cost } \\
(\mathrm{PVRC})\end{array}$ & $\begin{array}{l}\text { External Rare } \\
\text { of Return } \\
(\text { ERR) }\end{array}$ & $\begin{array}{l}\text { Internal Rate } \\
\text { of Return } \\
\text { (IRR) }\end{array}$ & \multirow[t]{2}{*}{$\begin{array}{l}\text { Benefit Cost } \\
\text { Ratio (BCR) }\end{array}$} \\
\hline & \multicolumn{2}{|c|}{$\begin{array}{l}\text { Million taka in } 2007-08 \text { constant } \\
\text { prices }\end{array}$} & \multicolumn{2}{|c|}{$\%$} & \\
\hline Ginger & 135.01 & 81.15 & 312.50 & 32 & 3.75 \\
\hline
\end{tabular}

Note : $\$ 1.00=$ Tk. 80.00

Table 8. Foreign exchange savings from investment in ginger research

\begin{tabular}{llllll}
\hline Year & $\begin{array}{l}\text { Import (cif) } \\
\text { Price } \\
2007-08 \text { Taka }\end{array}$ & $\begin{array}{l}\text { Supply } \\
\text { Shifter } \\
\text { K (percent) }\end{array}$ & $\begin{array}{l}\text { Ginger } \\
\text { Production } \\
\text { (tons) }\end{array}$ & $\begin{array}{l}\text { Increase in } \\
\text { Production } \\
\text { From Research } \\
\text { (tons) }\end{array}$ & $\begin{array}{l}\text { Foreign } \\
\text { Exchange } \\
\text { Savings } \\
\text { (2007-08 Taka) }\end{array}$ \\
\cline { 2 - 6 } & A & B & C & D=BxC & E=AxD \\
\hline $2002-03$ & 50158 & 0.0078 & 42825 & 335.30 & 16817901 \\
$2003-04$ & 50986 & 0.0157 & 48185 & 754.52 & 38470364 \\
$2004-05$ & 46311 & 0.0313 & 49405 & 1547.26 & 71655143 \\
$2005-06$ & 43478 & 0.0548 & 57095 & 3129.16 & 136048856 \\
$2006-07$ & 42522 & 0.0861 & 63000 & 5425.81 & 230715207 \\
$2007-08$ & 36150 & 0.1174 & 63392 & 7444.87 & 269135542 \\
\hline \multicolumn{7}{l}{} & Total Foreign Exchange Savings: & Tk. & 762843013 \\
\hline
\end{tabular}

Note : $\$ 1.00=$ Tk. 80.00 


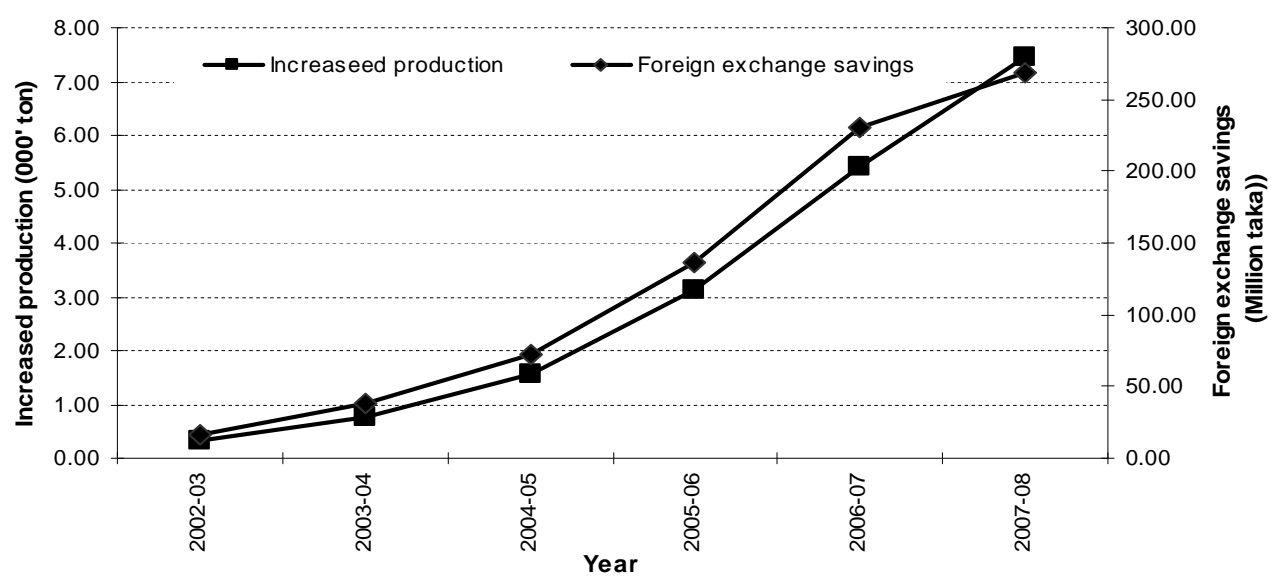

Figure 5. Foreign exchange savings due to ginger research and development over time

\section{Conclusions and Recommendations}

The empirical results indicate that the expenditure on ginger research and development paid a favourable rate of returns and the society were also enormously benefited out of it. The IRR to ginger research and development expenditure was found to be 32 per cent. A 32 per cent IRR on investment in ginger research and development is a good rate of return. The consumer's surplus is found to be very few only due to small open economy. However, this situation might not be a good sign for the economic prosperity. For the survival of the consumers, price support should be given by government.

The annual adoption rate of BARI Ginger-1 is not good because of non availability of seeds. Therefore, seed production programme should be undertaken largely by the government and non governmental organizations, so that the farmers can get quality seeds easily at a reasonable price.

\section{References}

Akhter, M. I., Rahim, M. A., Hasan, M. K., Alam, M. M., Zaman, M. M., Khan, M.A., Brahma, S. C. and Ahmed, M. M.
2006. Production Procedure of Ginger Crop (In Bangla). Ginger Research Centre, Bangladesh Agricultural Research Institute, Bogra.

Akino, M and Hayami, Y. 1995. Efficiency and Equity in Public Research: Rice Breeding in Japan's Economic Development. American Journal of Agricultural Economics, 57:1-10.

Alston, J. M., Norton, G. W. and Pardey, P. G. 1995. Since Under Scarcity: Principles and Practice for Agricultural Research. Evaluation and Priority setting. Cornell University Press, Ithaka. 237 p.

Ayer, H. W. and Schuh, G. E. 1972. Social Rates of Return and Other Aspects of Agricultural Research: The Case of Cotton Research in Sao Paulo, Brazil. American Journal of Agricultural Economic, 54:557-569.

BBS (1996-2012) Statistical Year Book of Bangladesh, Bureau of Statistics Ministry of Planning, Government of the People's Republic of Bangladesh, Dhaka.

Bonde, S. R. and Prakash, H. 2006. Garlic Cultivation in India. National Horticultural 
Research and Development Foundation, Nashik, India.

Bose T. K., Mitra, S. K., Farooki, A. A. and Sadhu, M. K. 1999. Tropical Horticulture. Naya Prokash, Calcutta, India. vol. 1.

Currie, J. M., Murphy, J. A. and Schmitz, A. 1971. The Concept of Economic Surplus and Its Use in Economic Analysis. Economic Journal, 18:741-798.

Dey, M. and Norton, G. 1993. Analysis of Agricultural Research Priorities in Bangladesh. Research Report, BARC, ISNAR, $300 \mathrm{pp}$.

Foster, A. D. and Rosenzweig, M. R. 2010. Microeconomics of Technology Adoption. Economic Growth Center Discussion Paper no. 984. Yale University: New Haven, USA.

Gardiner, J. C., Sanders, J. H. and Barker, T.G. 1986. An Economic Evaluation of the Prude Soft Red Winter Wheat Programme. Department of Agricultural Economics, Agricultural Experimental Station, Prude University, West Lfayette, $258 \mathrm{p}$.

Hertford, R. and Schmitz, A. 1971. Measuring Economic Returns to Agricultural Research. Resource Allocation and Productivity in National and International Agricultural Research. Minneapolis. University of Minnesota Press. 148-167 pp.

Nagy, J. G. 1991. Returns from Agricultural Research and Extension in Wheat and Maize in Pakistan. Research and
Productivity in Asian Agriculture. Cornell University Press. Ithaca. New York.

Nagy, J. G. and Furtan, W. H. 1978. Economic Cost and Returns from Crop Development Research: The Case of Rapeseed Breeding in Canada. Canadian Journal of Agricultural Economics, 26(1):1-14.

Nagy, J. G., and Alam, M. F. 2000. The Impact of Agricultural Research in Bangladesh: Estimating Returns to Agricultural Research. Project Report, BARC, Dhaka and International Fertilizer Development Centre, Muscle Shoals, Alabama.

Norton, G. 1993. Analysis of Agricultural Research Priorities in Bangladesh. Discussion Paper, No. 93-07, International Service for National Agricultural Research (ISNAR), Po. Box 93375.

Peterson, W. L. 1971. The Returns to Investment in Agricultural Research in the United States In: Resources Allocation in Agricultural Research, (ed.) W.L. Fishel.

Rusike, J., Mahungu, N. M., Jumbo, S., Sandifolo, V. S. and Malindi, G. 2010. Estimating impact of cassava research for development approach on productivity, uptake and food security in Malawi. Food Policy, 35(2):98-111.

Scobie, G. M. and Posada, R. T. 1977. The Impact of High Yielding Rice Varieties in Latin America-with Special Emphasis on Colombia. Series JE-01. CIAT. Calli. Colombia. 